\title{
QR-Code Assisted Learning Book: Scientific-Based Physical Learning Solution
}

\author{
Fauzi Bakri ${ }^{1}$, Sarah Salsabila ${ }^{2}$, Dewi Muliyati ${ }^{3}$ \\ \{fauzi-bakri@unj.ac.id ${ }^{1}$, sarsar.salsabila02@gmail.com², dmuliyati@gmail.com³ \\ Physics Education Department, Universitas Negeri Jakarta ${ }^{1,2,3}$
}

\begin{abstract}
Understanding the physics concept will be easier if the material can be presented in various forms. Quick Response Code ( $\mathrm{QR}-\mathrm{Code})$ can provide additional material in the form of videos, PPTs, or websites to facilitate the learning of physics concepts. The methods used in this study is research development (Research and Development), Dick and Carey model with the following steps: identify instructional goals, conduct instructional analysis, identify entry behaviors and learner characteristics, write performance objectives, develop criterion-referenced test items, develop instructional strategy, develop and select instructional materials, develop and conduct formative evaluation, revise instruction, develop and conduct summative evaluation. This study produced textbooks equipped with QR-Code for 12th-grade physics in the odd semester to display physics the materials enriched with various forms of media making it easier for students to understand the concepts learned.
\end{abstract}

Keywords: Textbook, Research and Development, QR code, High School Physics

\section{Introduction}

One of the natures of physics as a scientific process that requires scientific methods to obtain knowledge. The scientific method starts by compiling an appropriate hypothesis, designing an experiment to prove the hypothesis, and drawing conclusions. The scientific method can train scientific thought patterns to solve problems systematically, empirically, critically, creatively, and in control based on phenomena that occur [1]. Thus, the characteristics of physics learning are forming critical, creative, empirical, and systematic thinking patterns.

Building critical, creative, empirical, and systematic thinking patterns in 21 st-century physics learning are done by integrating knowledge skills, skills, and attitudes, as well as mastery of ICT. That mindset can be developed by providing supporting physics learning media. Based on the results of the study showed that $70.32 \%$ of students stated the lack of tools and books in learning physics made physics difficult to understand [2]. The lack of interesting physics textbooks as a learning medium causes the motivation of students to read and develop their knowledge [3]. On the other hand, each student has a learning style with a different representation. Learning resources are needed that display multiple representations to facilitate understanding of concepts [4],[5]. To face difficulties in education like this, we can integrate technology into learning media, digital technology can provide a significant change [6].

One technology that can be integrated into physics learning media is QR-Code technology. The QR-Code is an acronym for the Quick Response-Code which has become a popular type of 2D barcode due to its larger data capacity and higher resistance to damage [7]. QR-Code is a 
good way to share information from one source to another: from educators to students, from students to other students, even from students to educators [8],[9]. So educators can expand learning inside and outside the classroom by applying the QR-Code. The use of QR-Code in learning can make it easier for students to access material by using a smartphone, more involving students in the learning process, making it easier for students to store and share learning material, and attract the attention of students in the learning process [10].

Based on the description above, it is necessary to research to develop textbooks equipped with QR-Code in High School physics subjects.

\section{Methods}

This research was conducted in November 2017 until August 2019. The research began from the preparation of a research plan, product development, to the preparation of a research report. The research method used is The Research and Development (R\&D) concerning the Dick and Carey model. There are ten procedural steps, namely 1) identifying general objectives; 2) conduct a learning analysis; 3) analyze students' characteristics and learning context; 4) formulating learning objectives; 5) developing assessment instruments; 6) plan learning strategies; 7) developing and selecting learning material; 8) design and conduct formative evaluations; 9) make revisions; and 10) designing and conducting summative evaluations.

Data collection techniques used in this study consisted of two parts, namely: validation questionnaires and user ability test questions in the form of pre-test and post-test. Data sources are validators and users. The validator is a material expert and a media expert. Users are teachers and students.

\section{Result and Discussion}

The products produced in this study are textbooks equipped with QR-Code for high school physics class XII odd semester, consisting of materials in the Direct Current Circuits, Static Electricity, Magnetic Fields, Electromagnetic Induction, and Alternating Current Circuits. The book developed has several components, namely book skins consisting of 1) front skin; 2) back skin; and 3) back skin. Then the introduction to the book which consists of 1) french pages; 2) introductory page; 3 ) manual pages for the use of books, and 4) table of contents. The contents of the book consist of 1) chapter title page, 2) concept map; 3) description of material; 4) chapter summary; and 5) formative testing. At the end of the book, the book closes with a bibliography. The results of the textbooks in this study can be seen in Figure 1 below. 

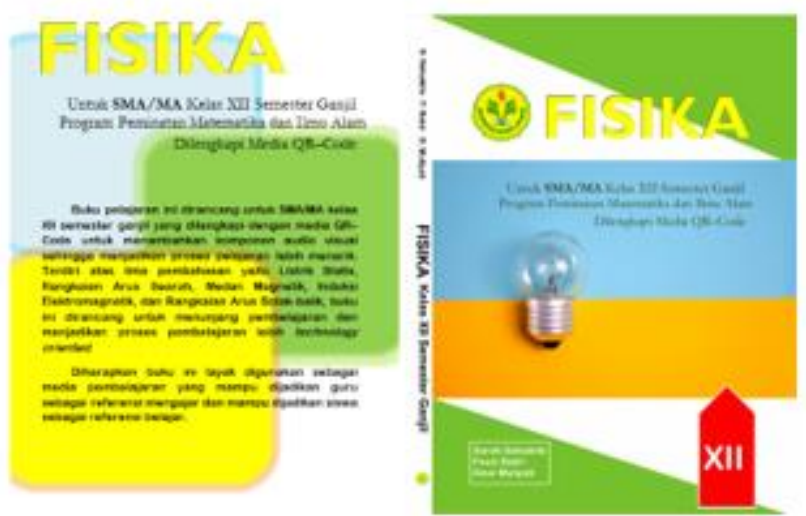

(a)

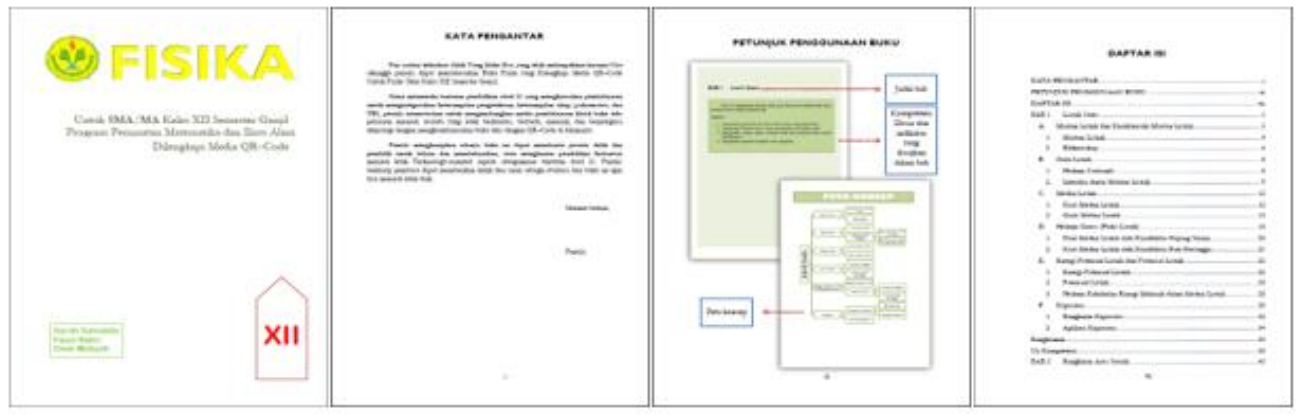

(b)
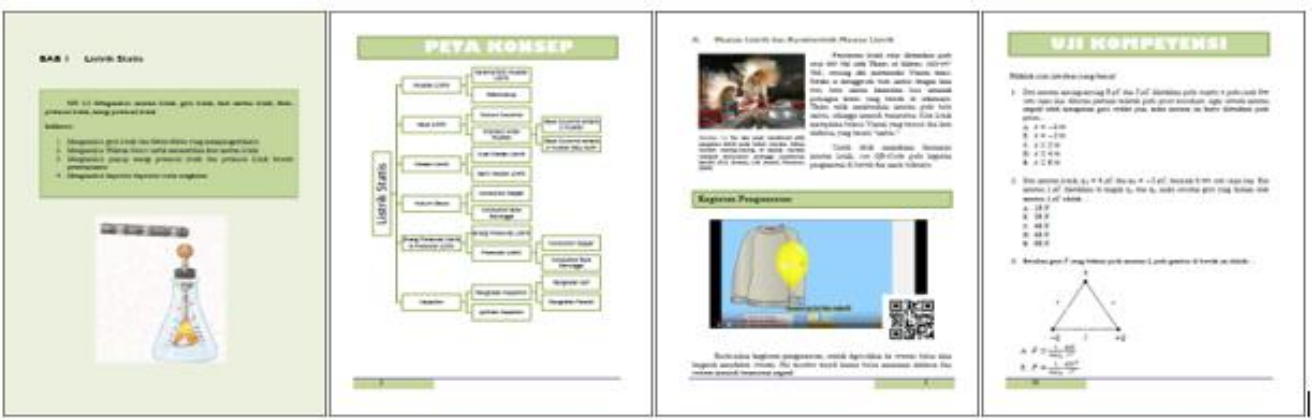

(c)

Fig. 1. Display of research products; a) book skins; b) introduction to the book; and c) contents of the book.

The development of the book passes the validation test, limited readability test, product trial by the user, and revises at each stage. In the validation test stage, books are tested by material experts and media experts. The material validation test has an average percentage of $89.16 \%$. The aspects tested can be seen in Table 1 and the aspect of the suitability of the contents of the material gets the highest points with a very decent category, so it can be concluded that the development of the material presented is by the applicable syllabus. 
Table 1. Material validation test results by material experts.

\begin{tabular}{llll}
\hline No. & Aspect & Percentage & Interpretation \\
\hline 1 & Suitability of Content & $92.00 \%$ & Very Good \\
2 & Language & $88.00 \%$ & Very Good \\
3 & Compatibility & $87.50 \%$ & Very Good \\
\hline Average & $89.16 \%$ & Very Good \\
\hline
\end{tabular}

The average obtained from the media validation test was $85.62 \%$ with a very decent category. The aspects tested can be seen in Table 2. Of the five aspects of the media validation test, the aspect of the functioning of the QR-Code gets the highest points with a very decent category, and the front cover page design aspect gets the lowest points with the proper category. The QR-Code developed as an attraction in this book is considered very feasible as a learning medium, both in terms of the quality of the video that is encrypted in it or terms of the feasibility of the material discussed in the video.

Table 2. Media validation test results by media experts.

\begin{tabular}{llll}
\hline No. & Aspect & Percentage & Interpretation \\
\hline 1 & Book Components & $86.00 \%$ & Very Good \\
2 & Font Sizes and Spaces in Books & $86.00 \%$ & Very Good \\
3 & Illustration of Book Content & $80.00 \%$ & Good \\
4 & Book Cover Page Design & $87.50 \%$ & Very Good \\
5 & QR-Code Media Functionality & $88.60 \%$ & Very Good \\
\hline Average & $85.62 \%$ & Very Good \\
\hline
\end{tabular}

After reading the readability test, the book was tested on products by two physics teachers with the results of $74.28 \%$ and $90.31 \%$ with a proper interpretation and very feasible as a learning medium. Then it is tested on students using pre-test and post-test. The results of the pre-test and post-test are then processed with the gain test presented in Table 3 below.

Table 3. Student's N-Gain Results.

\begin{tabular}{lllll}
\hline No. & Subject & Pre-test & Post-test & N-Gain \\
\hline 1 & KD 3.1 Direct Current Circuit & 43.00 & 52.00 & 0.13068 \\
2 & KD 3.2 Static Electricity & 30.00 & 51.00 & 0.29091 \\
3 & KD 3.3 Magnetic-Field & 18.33 & 41.61 & 0.28072 \\
4 & KD 3.4 Electromagnetic Induction & 23.33 & 53.33 & 0.38381 \\
5 & KD 3.5 Alternating Current Circuit & 22.50 & 43.33 & 0.25184 \\
\hline
\end{tabular}

Based on the data obtained, the $\mathrm{N}$-gain obtained is 0.13068 for direct current circuit material, 0.29091 for static electricity material, 0.28072 for magnetic-field material, 0.38381 for electromagnetic induction material, and 0.25184 for the material alternating current circuit. Seen all materials except electromagnetic induction material get a low category.

Electromagnetic induction material has a medium category. The results of the product trial showed a percentage of $74.14 \%$ in the feasible category. Although the book is considered feasible, the n-gain results obtained are low, this is likely because even though students are interested in the product, without further treatment of the product [11]. The second possibility 
is the time given to study the book is too short so students cannot understand the material to the maximum.

\section{Conclusion}

After going through several processes of validation testing by material experts and media experts, and product trials by teachers and students, physics textbooks equipped with QR-Code media for odd semester XII High-School Physics have the quality that is worthy of being used as learning material.

\section{References}

[1] Sunardi, P., \& Darmawan, A. B.: Fisika untuk Siswa SMA/MA Kelas X Kelompok Peminatan Matematika dan Ilmu-ilmu Alam, p 7. Penerbit Yrama Widya, Bandung (2016)

[2] Arief, M. K., Handayani, L., \& Dwijananti, P.: Identifikasi kesulitan belajar pada siswa rsbi: studi kasus di rsmabi se kota semarang. Unnes physics education journal pp. 5-10 (2012)

[3] Lesmono, A. D.: Pengembangan Bahan Ajar Fisika Berupa Komik Pada Materi Cahaya di SMP. Jurnal Fisika Vol. 1(1), pp. 100-105 (2012)

[4] Bakri, F., \& Muliyati, D.: Design of multiple representations e-learning resources based on a contextual approach for the basic physics course, Journal of Physics: Conference Series 1013p. 012037 (2018)

[5] Widianingtiyas, L., Siswoyo, S., \& Bakri, F.: Pengaruh Pendekatan Multi Representasi dalam Pembelajaran Fisika Terhadap Kemampuan Kognitif Siswa SMA, Jurnal Penelitian \& Pengembangan Pendidikan Fisika, Vol.1(1), pp. 31 - 38 (2015)

[6] Beetham, H., \& Sharpe, R.: Rethinking Pedagogy for a Digital Age: Designing for 21st Century Learning. Taylor \& Francis, New York (2013)

[7] Lin, P. Y., \& Chen, Y. H.: High payload secret hiding technology for QR codes. EURASIP Journal on Image and Video Processing (2017)

[8] Hopkins, D.: QR Codes in Education. In D. Hopkins, QR Codes in Education. Amazon's Kindle (2013)

[9] Durak, G., Ataizi, M., and Azkeskim, E.E., QR codes in education and communication, Journal of Distance Education, Vol 17 No 2, (2016)

[10] Burns, M.: Deeper Learning With QR Codes and Augmented Reality: A Scannable Solution for Your Classroom. Corwin Press, USA (2016)

[11] Permana, A. H., Muliyati, D., Bakri, F., Dewi, B. P., \& Ambarwulan, D.: The development of an electricity book based on augmented reality technologies, Journal of Physics: Conference Series 1157 p. 032027 (2019) 